\title{
The Pearls of the Molard of Lavours' Shelters
}

\author{
Philippe Hameau* \\ Department of Anthropology, University of Nice Sophia Antipolis, France
}

*Corresponding author: Philippe Hameau, Associate Professor, Department of

Anthropology, University of Nice Sophia Antipolis, Paris, France.

\author{
Received Date: October 01, 2018 \\ Published Date: October 26, 2018
}

\section{Introduction}

Robert Vilain and Jean-Michel Treffort (2010) suggest to attribute the engravings of the Molard of Lavours' shelter (Ain, France) to the transition of the Bronze and Iron Ages. They compare these engravings with those of Valcamonica (Lombardy, Italy) and certain sites of Savoy and Piedmont. If the dating was proved true, we could thus have there an off-centered and unpublished marker-pole of the prehistoric iconography, because far from the big centers of pre and protohistoric alpine area of engravings. Such a chronological proposal in this place can only draw the attention and arouses remarks. Is this hypothesis educated by convincing elements of comparison and reflection or can we imagine other chrono-cultural attributions and other hermeneutics for these figures? We propose here other conclusions.

\section{General presentation}

The shelter is opened in the northern face of the Molard of Lavours. It is a hill which rises within a vast horizontal space which is a former swampy zone. The swamp was drained and dried up. It served for the harvest of the feed, for the pasture of the cattle and for the exploitation of the peat. The zone became a Nature Reserve of 460 ha for the conservation of the flora and fauna and the acclimatization of bovine and equine species [1].

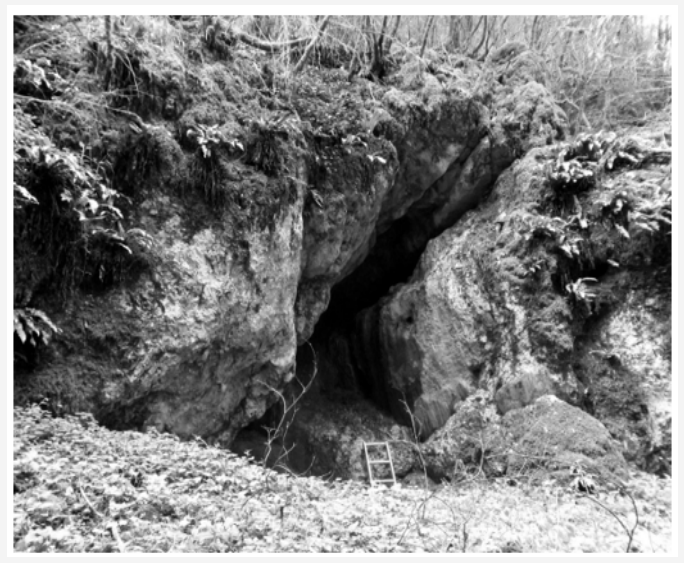

Figure 1: The shelter with engravings: General view.
The esplanade of the shelter is situated only a few meters away over the surface of the swamp. The shelter extends over about fifteen square meters (Figure 1). A sounding of $9 \mathrm{~m}^{2}$ was implanted there. The place is cold, and walls are submitted to gelifraction and to intense streaming. They are covered with calcite, natural grooves are accentuated by the frost and mosses colonize certain zones.

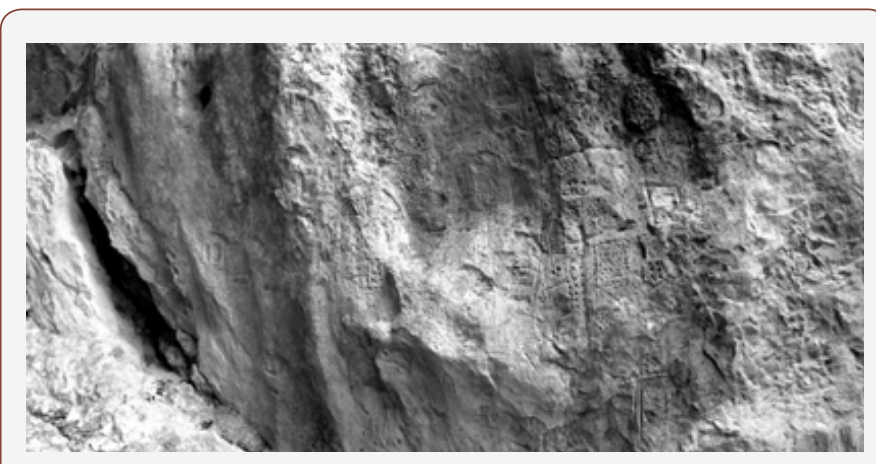

Figure 2: The engraved wall: General view.

Excavations were led from 1990 till 1992. They revealed the existence of two periods of frequenting of the site. The oldest one concerns the final Bronze III b and Hallstatt C, the most recent are the late Antiquity with several currencies struck in the IV ${ }^{\text {th }}$ century AD. The engravings of the site occupy mainly a panel of $1,50 \mathrm{~m}$ long on 1,20m high, on the western wall, over the sounding (Figure 2). The density of figures is important on two third top and right of the panel. The motives to the left and at the foot of this one, ring roads in the rest of the composition, form two groups of some units. The lowest figures are in $0,50 \mathrm{~m}$ of the current ground. The engraved zone is affected by the streaming and the center of the wall is subject to desquamation. Figures are essentially quadrangular plans (rectangle, squared, "in badge") and crosses with uneven branches (Figure 3). The latter are connected to very small cupules often grouped or presented in long alignments. These small cupules seem an important element of the panel, by their number and by the fact that they are present on the largest part of the motives. They are registered in the quadrangular plans, stacked or in 
connection with the lines which compose the other figures. They also represent groupings the global shape of which is quadrangular itself. No motive is a realistic representation.

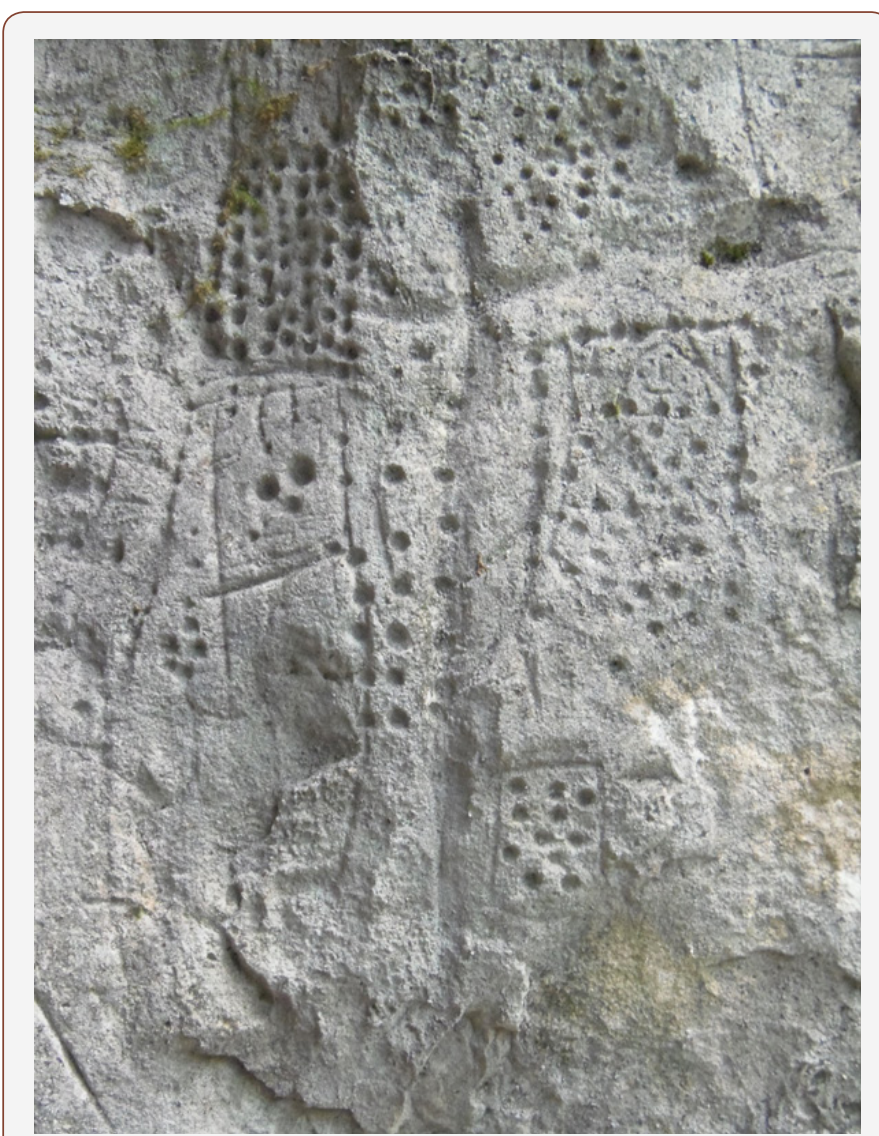

Figure 3: Quadrangular figures and Latine cross with microcupules.

This panel is especially perceptible as an accumulation of motives. There is no superposing between them. It is not really an organized composition implying links and/or rhythms in the iconography as the archaeologists think. The panel is undoubtedly realized in one same "graphic phase". This term expresses especially the stylistic coherence of figures. On the other hand, this graphic phase can consist of several episodes. These episodes are not taken away in time.

\section{The small cupules}

The peculiarity of the engravings of this site comes especially from the presence of the motive in micro-cupule with a density rarely equaled within engraved sites of the western part of the alpine world. However, it is necessary to explain the term of microcupule. It corresponds here to punctuated motives, in hollow, the outside diameter of which rarely exceeds 7 millimeters for a depth going from 3 to 6 millimeters. These sizes are thus very distant from those of the cupules that we observe in the rupestrian expressions in different periods. Here, micro-cupules are parietal and under shelter. Finally, they are realized by the rotation of a metallic point which provokes an imprint in truncated cone.

The micro-cupule like these ones we observe on the Mollard of Lavours' shelter exists in other certain iconographic groups. On these other sites, it can be alone, in the sense of a motive without obvious link with the other figures of the same site. It can be also associated with other motives according to recurring rules of juxtaposition and contraction of the figures. It can be also multiplied but in compositions where it corresponds to a realistic detail: eyes of a person, nails of a sole of shoe, etc.

In the Puits aux Ecritures (Engins, Drôme) [2], the three options described here exist: isolated micro-cupules; microcupules associated with cross with equal branches, with cross with uneven branches, with vertical short lines and with chevrons; micro-cupules in forms closed in a heel or in a sole of shoe. Some patronymics integrated into cartridges are also accompanied in the same way by micro-cupules. In both scialets of Ture (Autrans, Isère) [2], we observe crosses with small cupules and cartridges locking some micro-cupules. The rocky bar named Peyro Escrito (Olargues, Hérault) [3] owns the same micro-cupules, small-sized, in truncated cone, isolated or grouped in wholes including one or several alignments. In the last case, the groupings often constitute a quadrangular shape. Some micro-cupules are placed on the intersection of the various segments which compose a motive (Figure 4), such as cases the crossbow-shaped motive that occurs frequently at Olargues.

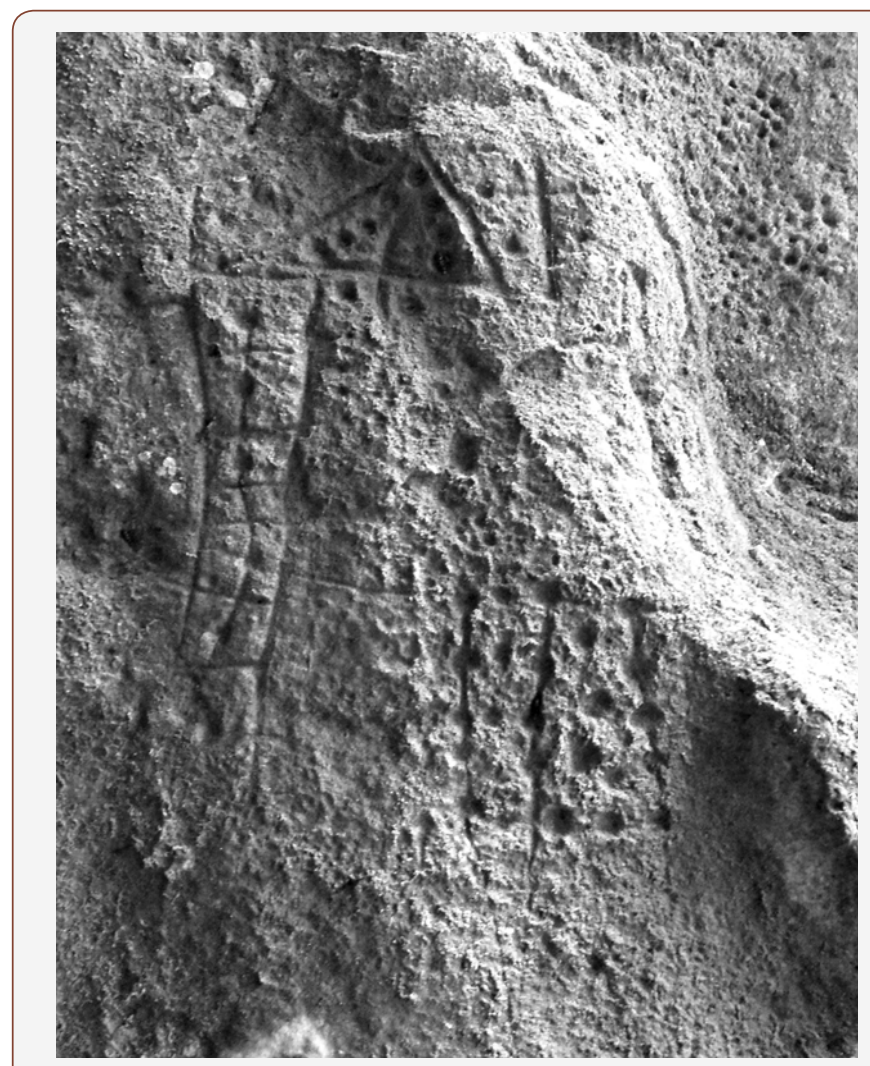

Figure 4: Quadrangular figures, crossbow-shaped motive and cross with micro-cupules.

Groupings of micro-cupules can be also registered in reticular motives topped with a chevron, called "house-shaped motive" by the various researchers. Much more far, to Tunkelwald (Venetia) [4] reticular figures on vertical support contain micro-cupules realized according to the same rotating technique. So, micro-cupules do not constitute an exceptional motive, but they are rarely as much plentiful as at the Molard of Lavours shelter. On the sites listed here, we observe the same locations of the cupules as those visible to Lavours. 
However, these sites are not the ones that Robert Vilain and Jean-Michel Treffort propose as comparison. Their argument takes into account sites where cupules turn out numerous, but without any similarity, neither of support, nor technique, nor of style. The figures of Valcamonica are indicated and in the first place the famous mappa of Bedolina [5]. The site of Lozes in Aussois (Savoy) also makes reference for its groups of cupules registered in square figures.

These two researchers retain thus, first, the insertion of cupules within quadrangular motives. However, for each of these sites, cupules are of clearly more important size. They are realized by percussion on a horizontal and outdoor support. They are associated with other figures which are absent into the engraved panel of the Molard of Lavours' shelter. In fact, the researchers implicitly reacted to the representation of punctuations registered in a quadrangle, but they did not understand that the technical and stylistic dimensions of the motives are not simply an answer to the material support. They are choices which we can consider also as cultural ones.

\section{Chronological Propositions}

Punctuations included in closed forms exist since the upper Paleolithic until todays. However, they have not inevitably the shape of those of the shelter of Molard. To try the chronological approach, we thus consider only the micro-cupules which are made by rotation of a metallic point and which are organized on a vertical support according to the modalities presented higher.

Thus, the iconography of the sites which we retained as comparison do not belong to a pré or protohistoric corpus. The figures of the Puits aux Ecritures are attributable to the modern and contemporary periods. For this site, the realization of the cupules is rather to be placed in the second half of the XVIII ${ }^{\text {th }}$ century and during the XIX ${ }^{\text {th }}$ century. The figures of the scialets are contemporary the previous ones. At Ubine, engravings were realized in the second half of the XIX ${ }^{\text {th }}$ century and the first decade of the XX ${ }^{\text {th }}$ century.

Engravings of Ubine cannot have been made before 1100 ap. J.C. The figures of Peyro Escrito would be of the chronological phase 6 of Campmajo (2015) [6]: between 1100 and 1400 AD. The groups of cupules could even be placed afterwards because all of them overlap the other figures. On the same site were traced houseshaped whose motives outlines lock sometimes groups of cupules, motives that are by the dimensions and the style to the "housesection" shaped ones which we observe in the cliff of Ubine and which are dated very recently.

On most of these sites, the cross with uneven branches, or Latin cross, is present. Sites evoked by Robert Vilain and Jean-Michel Trefford can include cruciform motives, but they belong to other iconographic corpuses. At the Molard of Lavours' shelter, crosses are realized and associated according to precise conventions, different from those known during the Protohistory. Thus, the iconographic analysis of the engravings of the shelter of Molard shows that these belong to much more recent dates. They would be to place between the end of the XVII ${ }^{\text {Ith }}$ century and the beginning of the $\mathrm{XX}^{\text {th }}$ century AD.
Other argument of former researchers is the attendance of places between the final Bronze and the First Iron Age. The chronological allocation is completely correct of course, but do we have to come and stay with the furniture to mark the walls of a site? The cause and effect of relationship is neither systematic, nor even current. We can imagine uses of the shelter for diverse practices which do not leave tangible tracks except for the apposition of motives on the rock. Finally, for recent dates proposed here, it is equally possible that recent vestiges are not taken into account.

\section{The Shelters A and B of the Molard}

In fact, the paper of Robert Vilain and Jean-Michel Trefford says nothing of the base in carved stone which is in front of the hall of the shelter, in $5 \mathrm{~m}$ of the sounding and was bearing a cross. It does not quote either the second shelter located $15 \mathrm{~m}$ from the first one, where we can see the tombs of four members of the Drujon de Beaulieu family. The shelter with engravings was not thus isolated when the second one became a family vault. All these arrangements date since the XIX ${ }^{\text {th }}$ century: 1841 for the base of the cross, between 1857 and 1872 for the gravestones of the second cavity. The base with its cross would indicate the sacred character of the place in general: of the place with both cavities. Accordingly, there is a shelter A (with engravings) and a shelter B (with tombs). In fact, when the second one is used for sepulchral practice, it seems that all the place have been conceived as the same sacred space.

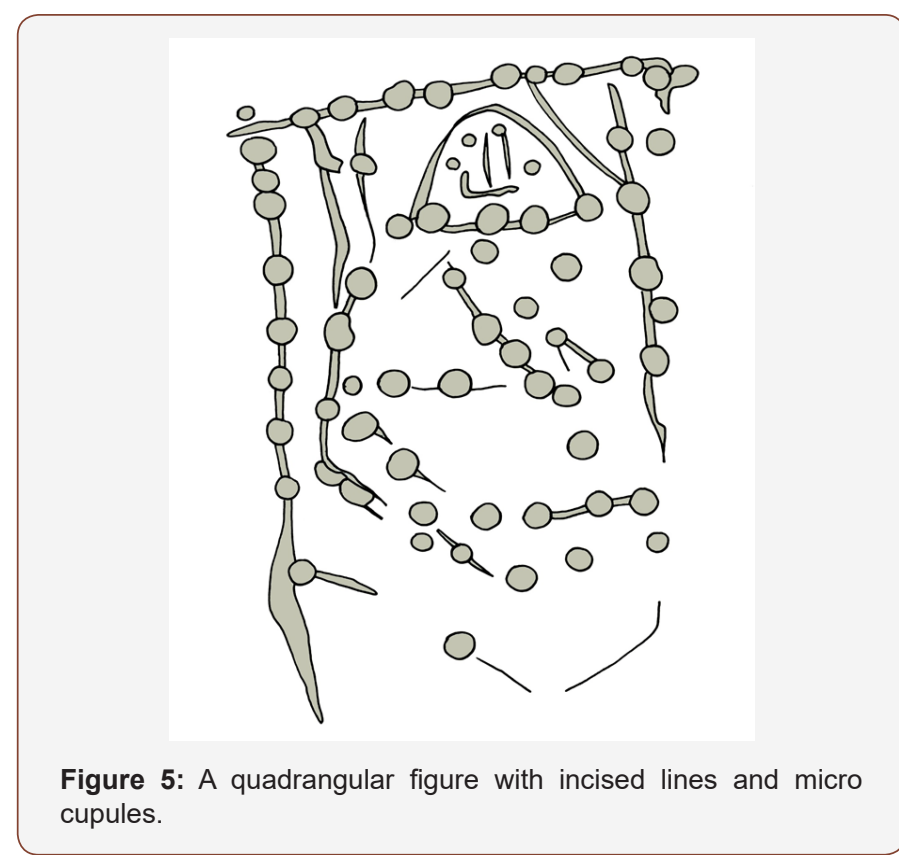

The shelter B measures $5 \mathrm{~m}$ of depth for $3,20 \mathrm{~m}$ of wide and is thus hardly smaller than the precedent. It is walled up in façade and on the western side. Its front door is framed by an embrasure of carefully cut, calcareous blocks similar to the in it stones which establish the base of the cross ( Figure 5). The inscription HIC PAX is engraved on the girder in big letters. Inside, a space of $2,80 \mathrm{~m}$ of length, on the ground in hard-packed surface gives on to a stage placed in $0,75 \mathrm{~m}$ over this one. Four steles of different forms occupy the edge (Figure 6). Behind these ones, the superior paving stone of a vault is sprinkled with fragments of human skeleton: the grave was desecrated. From left to right, steles belong to Julien Drujon 
de Beaulieu (in August 7th, 1797-May 18th, 1870), to Marie-Julie Drujon de Beaulieu (in February $2^{\text {nd }}, 1807$ - February $7^{\text {th }}, 1872$ ), Henri Drujon de Beaulieu (in March $7^{\text {th }}, 1842$-August $21^{\text {st }}, 1857$ ) and to François Clément Drujon de Beaulieu (in March 21 ${ }^{\text {st }}, 1805-$ September 1872). Steles are in the twilight and even when the door is opened, the embrasure allows only a rather low light to pass. The place is particularly wet, and the reliefs of walls are hidden by the calcite.

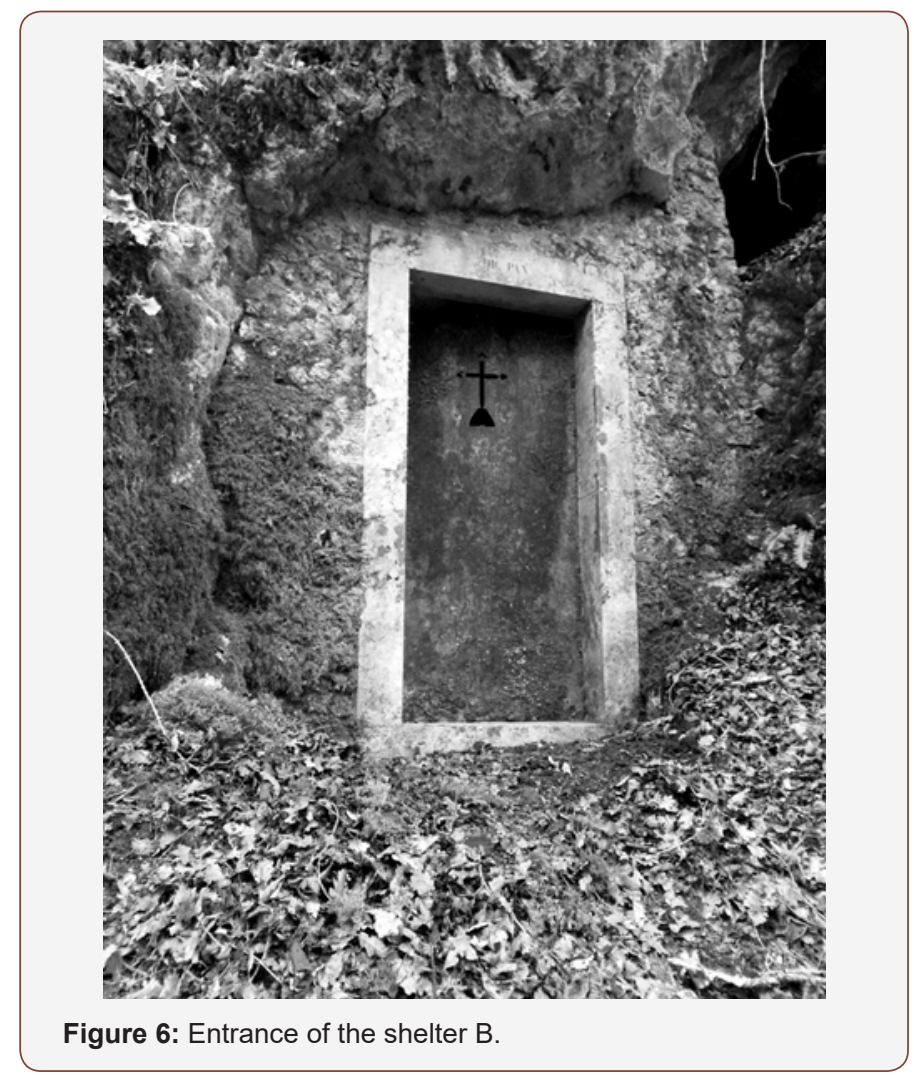

The Drujon de Beaulieu family is native of Lavours. A manor house belonging to her is visible on the side of the Molard. In the village, a chapel dedicated to saint Jean-Baptiste was built by the family by 1891 . Some papers in the Department archives of Isère indicate the participation of Laurent-Clément Drujon de Beaulieu to the assemblies of the nobility of the Bugey in 1789. His son, François-Clément is led in prison in 1797 and joins then the Imperial guard at 18 years old. He is lieutenant in the regiment of the Polish Lancers in 1812, at the time of the Russian episode of the Napoleonic wars. He withdraws in his castle of Lavours in 1815 and becomes Judge in the court of Belley by 1827 . He is elected a mayor of his municipality in 1848 and renewed in these functions by imperial decree of July $17^{\text {th }}, 1852$. He is magistrate during the Second Empire and dies in 1872. From his marriage with Juliette (or Julie) Combet, he has several children of whom Henri who dies accidentally by drowning at the age of five. For that reason, doubtlessly, the epitaph of Henri's grave adds: "He was pious, good and devoted - My God, should our pain affect you, be good for him" - P.P.L (pray for him)".

\section{Marks of Prayers}

Pray for him. This prayer is not so easy in the seclusion and the darkness of the shelter B. It is doubtlessly easier in the shelter A. The atmosphere of the place, its status and thus its configuration bring me to propose another hypothesis for the engravings of this first shelter: micro-cupules, which are quantitatively the most important motives, would be what we call "pearls", that is marks of prayers. These pearls are plentiful on the external and internal walls of churches and chapels, on the side of the other motives as the crosses and the calvarias. The most complete inventory of these motives was realized by Christian Montenat and MarieLaure Guiho-Montenat (2003) [7]. It concerns the outer walls of the religious buildings of the Parisian Basin. However, these "perforations" are not confined in the Northern France. Copies of these cupules, aligned or grouped, are present in many chapels of the South of France.

These micro-cupules are thus ordered in long, simple, double or multiple alignments. They can be placed so that they describe a circle, a sun-shaped figure, a cross or a Calvary. They can be grouped to form a rectangular motive and they are or not locked in one cartridge. Cupules either bound both extremities of vertical short lines or are placed between four branches of the Latin crosses. Some quantities of micro-cupules are recurring: 8, 9, 10, 12. "The association [of the micro-cupules] with epitaphs and, even more usually still, with crosses, comes to support this interpretation of marks of prayers" [7].

We observe circles of micro-cupules where an element of which is regularly wider (every 8 or 10 pearls) or a small cross in appendix of these circles. These examples explicitly make a reference to the representation of rosaries to memorize better the number recited. Accordingly, the micro-cupules of the shelter A could be these marks of prayers: grains of rosary which we represent by groups or alignments. That these micro-cupules are also organized according to a Latin cross (or other segmented motives) is just a different way to make sure of the number of the accomplished prayers: every compartment or every segment of line must be "cupuled" before we do not stop the prayers (Figure 7). Thus, the cartridge which line the groups of micro-cupules express graphic episodes: a limited moment of attendance on the site during which a precise number of prayers was made, by one or several individuals.

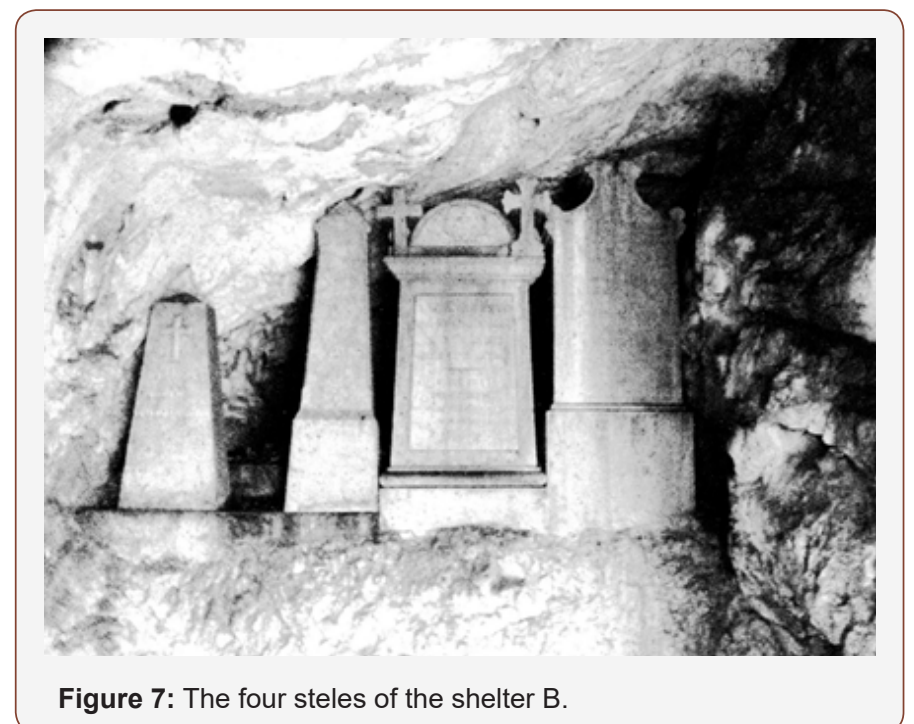

Christian Montenat and Marie-Laure Guiho-Montenat (2003: 47) think that the association of the cross or the calvary with microcupules reveals prayers for a deceased: the cross is then moreover as the "funeral cross", that of the Christ's martyrdom. The metallic 
door of the shelter B is decorated with such a Calvary. Looking at the years which are close them, dates given by researchers for these micro-cupules engraved on the walls of churches and chapels join essentially between the middle of the XVII ${ }^{\text {th }}$ century and the middle of the XIX ${ }^{\text {th }}$ century. These marks do not disappear during the XIXth century. They are less numerous because competed by the writing of patronymics and sometimes by epitaphs or invocations.

The example of the shelter of Molard is a little bit particular because it is not probably a space dedicated to a saint or to the Virgin. It is a place made sacred for the eternal rests of the members of a family. If the shelter B has explicitly a function of family vault, thus the shelter A would be the oratory where occasional practices of worship took place. The only vestiges, which we have of it are the marks on the walls, very specific because repeating in hundreds of copies the same cupule-shaped motive [8,9].

\section{Conclusion}

So, there is another alternative for these engraved motives that was proposed here. Of course, it is a hypothesis, because without known written proof we can only propose guesses for the former documents. To make this proposal, it was necessary to take into account the spatial context in which are registered engravings and the whole set of the elements of the iconographic corpus in order to realize an internal analysis of the documents. Rather than to look for points of comparison on long distances or in distant times, rather than to rule out the embarrassing graphic elements, the chronological and iconographic links were looked for in a restricted regional frame. It is since these temporal and semantic closeness's that the hermeneutics of the figures of the Molard of Lavours was envisaged. The idea that the marking of the wall could be only very former and come along automatically with an abandonment, voluntary or not, of movable vestiges seemed to have to be revised. On the contrary, the acts of worship which we suspect leave only rarely tracks with on the ground and do not often arouse the marking of the wall. Without this need, inherent to the Man, to count everything, it is not sure that we would have this memory subtlety which consisted in indicating here, by small cupules, the number of the prayers realized on the site.

\section{Acknowledgement}

None.

\section{Conflict of Interest}

No Conflict of Interest.

\section{References}

1. G Pautou, Y Majchrzak, O Manneville, R Gruffaz, D Moreau (1991) Dynamique de la végétation et gestion de la réserve naturelle du marais de Lavours (Ain). Revue de géographie de Lyon, vol 66, n¹, Connaissance de la friche pp. 61-70.

2. Ph Hameau, D Vaillant (2000) Témoignages d'art schématique d'époque moderne à l'extrémité septentrionale du Vercors. Bulletin de la Société Préhistorique Ariège-Pyrénées, IV, pp. 117-138.

3. R Guiraud (1960) Les gravures rupestres d'Olargues (Hérault), Revue d'Etudes Ligures. n²6, fasc.1-4, pp. 243-256.

4. A Arcà, A Fossati (1995) Sui sentieri dell'arte rupestre. 184p, Torino, Italy.

5. R Vilain, JM Treffort, E Borelli, C Ughetti, J Argant (2010) Un abri sous roche protohistorique à parois gravées : l'abri du Molard à Lavours (Ain, France). Actes de la première rencontre d'archéologie de Briord, pp. 6985.

6. P Campmajo, D Crabol (2016) Les roches gravées du Val d'Enfer à Olargues, Sources, les Cahiers de l'Âne Rouge. ${ }^{\circ}{ }^{\circ}$, pp. 31-55.

7. Ch Montenat, ML Guiho-Montenat (2003) Prières des murs - graffiti anciens aux murs extérieurs des églises. Mémoires du GEMOB, Beauvais, France, p. 206.

8. P Campmajo (2012) Ces pierres qui nous parlent-gravures rupestres de Cerdagne (Pyrénées-Orientales) des Ibères à l'époque contemporaine. Ed Trabucaire, Perpignan, France, p. 642.

9. Ph Hameau à paraître Les gravures d'Ubine (Vacheresse, Haute-Savoie). Mémoires et Documents de l'Académie Chablaisienne, France. 